\title{
日本ジオパークの教育力とは何か
}

\author{
尾 池 和 夫*
}

\section{Learning from Japanese Geoparks}

\author{
Kazuo OIKE*
}

[Received 15 July, 2016; Accepted 22 October, 2016]

\begin{abstract}
Geopark activities in Japan began when the Japan Geopark Committee was established in 2008. From geoparks, we learn about relationships between the Earth and regional development through discussions focusing on the environment, resources, energy, and life within the context of challenges faced in the 21st century. The Japanese Archipelago was formed 16 million years ago around the Sea of Japan. Its islands are very diverse. Cooperative investigations on marine biological taxonomy reveal that species diversity is characterized by extremely high-biodiversity hot spots. The activities of the Global Geopark Network (GGN) have progressed steadily with 100 areas joining in 2014. The UNESCO general meeting in November 2015 for the first time included the GGN in an official UNESCO program. Geoparks of the GGN became the UNESCO Global Geopark. Geoparks are based on the activities of local citizens, which develop steadily through interchanges with voluntary learning societies and exchange meetings with guides. Connections are then established to encourage sustainable local activities.
\end{abstract}

Key words : Japan Geopark Committee, UNESCO, Global Geopark Network, geodiversity, sustainable local activity

キーワード：日本ジオパーク委員会, ユネスコ, 世界ジオパークネットワーク, ジオ多様性, 持続 可能な地域活動

\section{I. はじめに}

ジオパークの活動が，本格的にはじまったの は，日本ジオパーク委員会が 2008 年 5 月に発足 してからといえる。ジオパークは, 大地の仕組み を学び, 大地の恵みを地域振興に活かし, 地球の ことを知ってもらう公園であるという説明をしな がら運動をはじめた。地球環境, 資源, エネル ギー，生命のことなど，21世紀のさまざまな課 題を議論するときにも, 地球の仕組みを理解して 議論しなければ意味がないと，今でも私は思って
いる。ジオパークはそのための公園である。 2016 年 10 月現在, 日本には 43 の日本ジオ パークが，日本ジオパーク委員会によって認定さ れている。そのなかで 8 地域がユネスコ世界ジ オパークに参加している。2009 年 8 月中国泰安・ 世界ジオパークネットワーク（GGN）事務局会 議において洞爺湖有珠山, 糸魚川, 島原半島の 3 地域が，2010 年 10 月にギリシャ・レスヴォス島・ GGN 事務局会議において山㓌海岸が，2011年 9 月にノルウェーのランゲスン・欧州ジオパーク ネットワーク会議において室戸が，2013 年 9 月

* 京都造形芸術大学学長

* Kyoto University of Art and Design, President, Kyoto, 606-8271, Japan 
に韓国 済州島・アジア太平洋ジオパークネット ワーク国際シンポジウムにおいて隠岐が，2014 年 9 月にカナダのストーンハンマー・第 6 回ジオ パーク国際ユネスコ会議において阿蘇が，2015 年 9 月に第 4 回アジア太平洋ジオパークネット ワーク山院海岸シンポジウムにおいてアポイ岳 が，それぞれ世界ジオパークに認定された。

2015 年 11 月 17 日, ユネスコ総会の本会議に おいてジオパークのユネスコ正式事業化の議案が 可決され, 国際地質科学ジオパーク計画 (International Geoscience and Geoparks Program, IGGP）としてユネスコの正式事業となった。こ れに対応して, 特定非営利活動法人日本ジオパー クネットワーク理事長の米田 徹が，2007 年に日 本ジオパーク連絡協議会を結成し，2009 年には これを発展させて日本ジオパークネットワークを 設立したこと, 現在約 200 の市町村がネットワー ク会員地域を構成する市町村となっていることな どを指摘してコメントを述べた。これにより日本 では 8 か所のユネスコ世界ジオパークが活動す ることになった。

それら 8 か所の特徴が, 日本ジオパークネッ トワークのページでは大略次のように紹介されて いる。それらを今後のジオパークのあり方を考え るためのヒントとしたい。

（1）洞爺湖有珠山（初認定日：2009.08.22）

活発な火山活動で景色を変え続けてきた世界で も類をみない変動する大地を体感できる場所であ る。噴火災害遺構の保存と公開による防災と減災 の教育が高く評価されており，火山がもたらす美 しい景勝や温泉, 食材などの大地の恵みを実感で きる。

（2）糸魚川（初認定日：2009.08.22）

日本列島を東西に 2 分するフォッサマグナの 西側の境界である糸魚川-静岡構造線がジオパー クエリアの中心を通る。縄文時代から古墳時代に かけて北海道から沖縄, 朝鮮半島へと広がったヒ スイがある世界最古のヒスイ文化の発祥地であ る。

（3）島原半島（初認定日：2009.08.22）

「人と火山の共生」をテーマに世界的な活火山

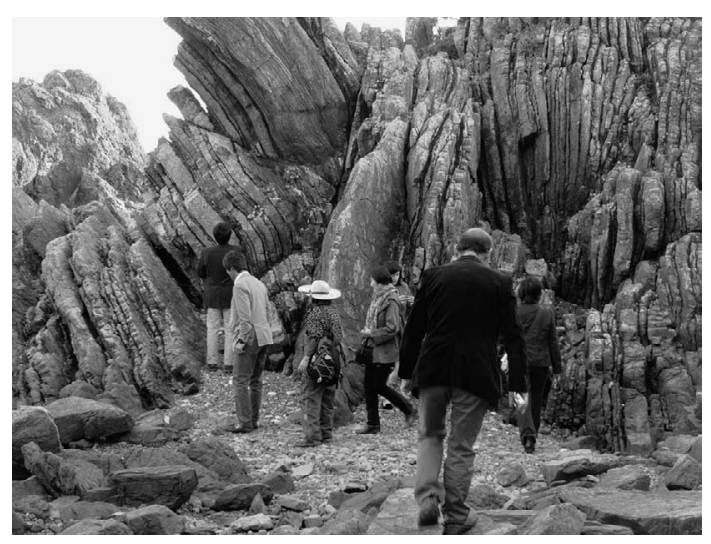

図 1 室戸ユネスコ世界ジオパークの砂岩泥岩互層 を見る。

Fig. 1 Alternated beds of sandstone and mudstone in Muroto UNESCO Global Geopark.

である雲仙火山による災害と復興を体感できる。 雲仙普賢岳の平成噴火をはじめとした火山災害か らの復興を学び，泉質が異なる温泉群や豊かな湧 水, 大地の恵みを五感で楽しむことができる。

（4）山陰海岸（初認定日：2010.10.04）

日本列島が大陸の一部であったときから，日 本海形成を経て現在に至る歴史を，多彩な海岸 地形や内陸の滝や渓谷などで見ることができる。 1929 年，松山基範博士により発表された「地球 磁場逆転仮説」の発見の舞台となった玄武洞など がある。

（5）室戸（初認定日：2011.09.18）

プレート運動による地殼変動がきわめて大きい 地域で，それによって形成された海成段丘が有名 である。また，大陸プレートと海洋プレートの境 界で新しい大地が誕生するという付加体の形成が 研究された舞台である（図 1)。

（6）隠岐（初認定日：2013.09.09）

日本海の風浪に浸食された海岸の景観がある。 離島でありながら大陸に類似した地質をもち，そ の来歴，地理によって独自の生態系と多様な時代 の文化が保存されており, 文化, 生物, 地質の多 様性が絡み合った景観が楽しめる（図 2)。

（7）阿蘇（初認定日：2014.09.23）

約 9 万年前の噴火によって形成された独特の 


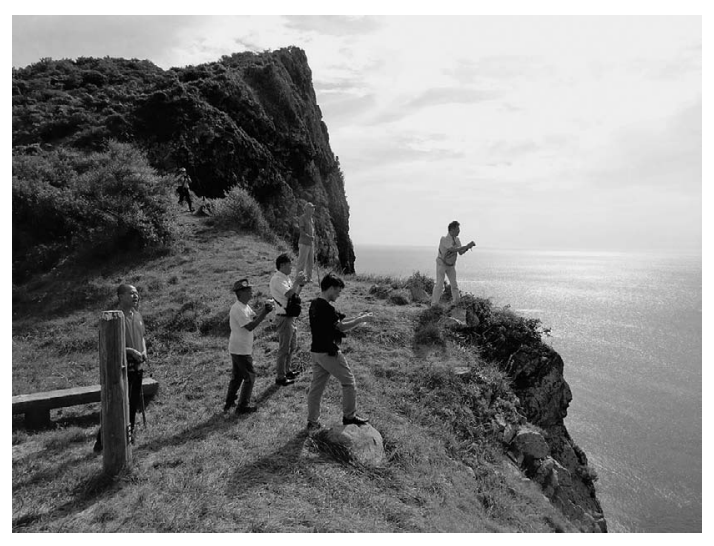

図 2 隠岐ユネスコ世界ジオパークの赤壁を見る.

Fig. 2 Red cliff in Oki UNSECO Global Geopark.

地形や地層，噴火がもたらした日本各地への影響 など，巨大カルデラに刻まれた噴火の記憶を辿る ことができる。カルデラのなかには 5 万人の人 びとが暮らしており，火山との共生に伴い，独自 の文化と生活を築いている。

また，2016 年熊本地震による被災地が含まれ る。

（8）アポイ岳（初認定日：2015.09.19）

プレートの衝突によって地球内部のマントルの 一部が顔を出した橄欖岩体からなるアポイ岳と, その特異な岩体に影響を受けた固有の高山植物群 落が見られる。先住民族アイヌの文化伝承など, 古くから交易の拠点として栄えてきた歴史にも触 れることができる。

\section{II. 日本列島の成り立ち}

日本列島は， 1600 万年前ころに日本海が拡大 してできた。列島の地層ができた歴史はたいへん 多様で，例えば隠岐には約 30 億年前の鉱物があ り, 本州では 1 億 2 千万年前の恐竜の化石が出 現し，あちこちに高品質の金銀が採掘され，縄文 時代の鏃が掘り出されている。日本列島全体にわ たって, 花崗岩の基盤が広く分布し, 古い珊瑚礁 が隆起して多くの石灰岩台地をつくった。南大東 島のように海のプレートの一部が海面上に出現し ている場所さえある。
さらに，日本列島の周辺の海は，国際プロジェ クト「海洋生物のセンサス」の一環としての日本 の約 50 名に及ぶ海洋生物分類学研究者の協力に よる調査によって，種多様性がきわめて高い生物 多様性のホットスポットであることが明らかに なった。

このような日本列島とその周辺の海は, 世界的 にみてもたいへん特徵的な地域であり, 日本列島 のどの地域をとりあげても，ジオパークとなるた めの基本である大地の特徴をもっている。その特 徵を地域の歴史のなかで育まれた文化を支える基 本的な地球の条件であるとの認識のもとに, 科学 的な知識を誰にでも理解できる形に翻訳して伝え る仕組みが展開されることによって，ジオパーク となる条件が生まれるのである。そのような日本 ジオパークの運動の展開とその教育力をさまざま の視点から考えてみたい。

\section{III. 変動帯の文化}

日本列島は，北欧などの安定大陸と異なり，巨 大地震や巨大噴火とそれらによる津波を自然の基 本的な特徴とする変動帯にある。その歴史が上に 述べた大地の多様性を生み出し, その変動帯の人 びとは自然災害から立ち上がりながら文化を育 て，歴史を築いてきた。

例えば，京都盆地には 1300 年に及ぶ悠久の都 の歴史があり，活断層のつくった盆地に蓄積され た堆積層の地下水をもとに茶の湯が生まれ, 湯葉 や豆腐や和菓子が発達し, さらに清酒が醸造され た。さまざまな時代の文化が活断層盆地の堆積層 の水から生み出されてきた。そのような文化を私 は「変動帯の文化」と呼び，ユネスコ世界ジオ パークネットワークのなかでは, とくにその点 を特徴として，日本ジオパークを位置づけたいと 考えている。

変動帯の大地の恵みを活かした人びとの生活 と文化の歴史を学び, 土地の産物を味わい, 大地 の仕組みを学ぶというジオパークを展開してい くことが, 未来に向かっての日本の豊かな暮ら しのために，大切なことの一つである（尾池ほか， 2011)。 


\section{IV. 日本列島の自然を護る仕組み}

日本の近代の歴史のなかで，国全体にわたる制 度としてどのような仕組みがつくられてきたかを 概観して，それらとジオパークの活動とを比較し ておきたい。

まず，天然記念物の制度である。

国が指定する天然記念物は「文化財保護法」 （1950 年制定）に基づき，文部科学大臣が指定す る。所管は文化庁で，文化財部記念物課文化財鑑 査官が担当する。文化財保護法の前身は 1919 年 （大正 8 年）に公布された「史蹟名勝天然紀念物 保存法」である。

次に国立公園の制度である。

1931 年に自然公園法の前身である国立公園法 が施行され，1934 年 3 月 16 日に瀬戸内海国立 公園, 雲仙国立公園, 霧島国立公園の 3 か所が 最初の指定を受けた。

3 番目に世界遺産である。

日本は, 先進国では最後の 1992 年に世界遺産 条約を批准し, 同年 6 月 30 日に 125 番目の締約 国となった。日本についての発効は同年 9 月 30 日であった。

4 番目が地質百選の制度である。

2007 年 5 月 10 日に第 1 次選定として 83 か所 が選ばれ，2009年 5 月 10 日「地質の日」に第 2 次選定として 37 か所が選ばれた。今までに合計 120 か所の地質百選が選定されている。

さらにエコッーリズムの活動である。

エコツーリズム推進法が 2007 (平成 19）年 6 月 27 日法律第 105 号として生まれた。それをも とに環境省が主導してエコツーリズムを進めるた めの枠組みを定めた。参加省庁は環境省のほか国 土交通省, 農林水産省, 文部科学省である。翌年 の 4 月 1 日から施行された。

そしてジオパークの活動が生まれた。

日本では 2008 年に国内のジオパークを認定す る機関として, 日本ジオパーク委員会 (Japan Geopark Committee, JGC）が発足した。JGC が 2008 年に認定した地域により，2009 年に日 本ジオパークネットワーク (Japanese Geoparks
Network, JGN）が設立された。2009 年 8 月 22 日, 洞爺湖有珠山 (北海道), 糸魚川 (新潟県), 島原半島（長崎県）の 3 か所が，そのときの世 界ジオパークネットワーク（GGN）に加盟を認 められ，世界ジオパークとなった。

\section{V. 世界と日本のジオパークの歴史}

ユネスコとジオパークの関係の歴史を概観する と次のようになる。

1997 年, UNESCO Geopark Programme とし て提唱されたが正式なプログラムとはならなかっ た。 2001 年 6 月，ユネスコ執行委員会の決定に より，ジオパークを推進する各国の努力を支援 することが決まり，2004 年，ユネスコの支援に よる世界ジオパークネットワークが設立された。 これは世界遺産のような条約による多国間プロ グラムではないのが特徵である。価值の高い地 質遺産，質の高い活動が評価された地域がジオ パークネットワークの一員に認定された。この とき，欧州ジオパークネットワーク（European Geoparks Network）の 17 地域と中国地質公園 の 8 地域が世界ジオパークネットワーク (Global Geoparks Network, GGN）を構成した。

このころ, Gray（2004）によるジオダイヴァー シティー (ジオ多様性) の概念が提唱され，この 考え方も一方で重要な概念として日本のジオパー ク活動に影響を与えることとなった（国際環境研 究協会, 2005)。

ジオパークの概念そのものに関しては，ユネス コの地質部長であった Wolfgang Eder (2007) によるジオパークの発展に関する第 2 回国際シ ンポジウムでの, 世界ジオパークネットワークの 概念のなかでも国内ジオパーク活動の展開につい ての考え方が日本のジオパーク活動にも影響を与 えた。Patzak and Missotten（2007）による『地 質ニュース 635 号』での論文でジオパークの概 念が日本語で詳しく伝えられた。ここでは，日本 でもジオパーク活動が準備されていると紹介され ている。

世界ジオパークネットワークの活動は着実に 進み, 2014 年には 100 の地域が加盟しており, 
2015 年 11 月のユネスコ総会において，はじめ てユネスコの正式プログラムに組み込まれること となった。これによって GGN に加盟する地域は 「ユネスコ世界ジオパーク」と呼ばれることと なった。

ユネスコはジオパークの役目について，あらた めて次のように述べている。

（1）地質学的重要性に加えて考古学的, 生態 学的, 文化的な価值が 1 つ以上認められる。

（2）持続可能な社会・経済発展を促進する経 営計画があり，ジオッーリズムが実現している。

（3）地質遺産（geological heritage）の保存, 改善方法, 地質科学や環境問題の教育が行われて いる。

（4）公共団体や地域社会ならびに民間による 共同行動計画が成り立っている。

このような条件のもとで, 地球遺産（Earth heritage）の保存の実践例が示され，持続可能な 開発戦略への融合と国際ネットワークの一翼を担 うことの意義が強調されている，ユネスコのプロ グラムになることによって，より強い国レベルと 国際レベルでの政治的承認を受けることができる こと，ユネスコの高品質な価值を備えた世界ジオ パークへの発展が期待できること, 国際社会から の認知度が向上すること, より多くの人がジオ パークを認知するよい機会となること，国内でジ オパーク活動を行っている人びとの活動が世界に つながっていると実感できることなどが期待さ れ，ジオパークの活動が活気づくことになる。具 体的には，ユネスコのロゴマークが使用できるこ となどの利点がある。

もちろん，ユネスコの目的は「世界平和の実 現」であり, 教育, 科学, 文化を通じて人種・ 性・言語および宗教の差別をなくすことで世界平 和の実現を目指すことであり，ジオパークネット ワークにおける途上国支援金の拠出や人的支援な どが求められることも認識していなければならな い重要な概念である。

日本国内でのジオパークの認知度を知るため に，全国の新聞記事を「ジオパーク」というキー ワードで検索してみた。その結果によると，2003
年までの記事は存在せず, 2004 年にはじめて 1 件の記事があり，その後， 1 年あたり 17,24 , $162 ， 806 ， 1827 ， 2092$ と増加して，2011年に は 3540 件, その後も 3474,4444 と増加した。

これらの記事のなかで, 2004 年の 1 件は,「山 陰海岸の重要性説く, 香住地質学者らフォーラ ム」というタイトルの神戸新聞地方版の記事であ り，京都府から鳥取県に至る山陰海岸が 2003 年 に国立公園指定 40 周年を迎えたことを記念する フォーラムのなかで, 世界ジオパークに山陰海岸 を登録しょうという取り組みが報告されたという 内容であった。日本列島がユーラシア大陸から分 かれて山陰海岸が形成された過程, 動物の足跡化 石群が香住町内で見つかったことなども，そこで 報告された。

2008 年に 806 件と増えたときには，日本ジオ パーク委員会が発足したという記事が主であっ た。このとき日本の 15 地域でジオパーク連絡協 議会が活動していた。この時点では国内で加盟の 機運が高まっているとして, 洞爺湖有珠（北海 道), 糸魚川 (新潟県), 山陰海岸, 島原半島 (長 崎県）などが具体的に紹介されていた。

一方, 日本の旅行業界では新しい旅行商品の開 発が検討され, 例えばJTB 総合研究所では, 「着 地型旅行」というオプションが提起されていた。 着地型というのは，それまでの旅行商品が都市部 の旅行会社で企画される「発地型」であったのに 対する概念で，旅行目的地側の主導で行う旅行の スタイルを指している。旅行者の多様化にとも なって, 地元の人しか知らない穴場を楽しむ旅行 のスタイルが，地域資源を活かし，伝統産業を体 験し, 若い力と斬新な発想を生み出すものと考え られ，これがジオパークの考え方とよくあった旅 行と認識されるようになった。

\section{VI. 自然災害を学ぶ機能}

2012 年に島原半島ジオパークを会場として開 催された第 5 回ジオパーク国際ユネスコ会議の 最終日に読みあげられた「島原宣言」では，ジオ パークの活動に自然災害を学ぶという役目がある という条項が加えられた。日本ジオパーク委員会 
では安定大陸をおもな特徵とするヨーロッパのジ オパークに対して, 変動带の特徵をもつ日本のジ オパークの考え方をもち込むという点をとくに議 論していた。

また，先に述べた Eder（2007）のなかでも， 2004 年のインド洋の大津波のことが指摘され, 政治家や地球科学者や教師や旅行業界にとって 「地球システム」という概念を示すことの重要性 が指摘され，そのことが国際連合の提唱する「国 際地球年 (International Year of Planet Earth, IYPE）の趣旨に沿うものと述べられている。

例えば，日本ジオパークのなかでも，三陸ジオ パークは津波災害からの復興を中心の課題として いる（高木, 2012）。激震による大規模な地滑り や山腹崩壊，河道閉塞などの山地災害が相次いだ 栗駒山麓では, 治山や砂防工事が進んでいるが, 地震のすさまじさを示す痕跡を目の当たりにする 機会が少なくなった地域で，どのようにして内陸 地震の災害を後世に伝えるかという課題をもって いる。栗原市は, 内陸地震でできた荒砥沢崩落地 などを中核的地形と位置づけて，ジオパークとし てそれを保存し，活用する道を選んだ。地形の大 規模改変を伴う災害が起きても，復旧工事でもと の生活に戻ると人びとは災害のことを忘れてしま うであろうが，これをジオパークにするという賢 明な判断をすることができた。災害は，映像や写 真で残せるが，人びとの記憶という形で後世に伝 えることは困難である。栗原市では地元ガイドが 崩落地を案内しながら, 見学者に地滑りの仕組み を解説する。被災現場にはコンピューター画面に はない它いや感触があり, 迫力と現実味がある。

\section{VII. ジオパークの課題}

ユネスコと国際地質科学連合 (IUGS) で国際 地質科学ジオパーク計画 (IGGP) がまとめられ た。そこにユネスコ世界ジオパークの枠組みが描 かれている。

国際地質科学ジオパーク計画 (International Geoscience and Geoparks Programme, IGGP) は, 国際地質科学連合 (International Union of Geological Sciences, IUGS）との共同事業である
国際地質科学計画とユネスコ・グローバル・ジオ パーク (UNESCO Global Geoparks) の $2 つ の$ 活動を通じて実行される。

IGGPにおけるユネスコ・グローバル・ジオ パークは，国際的価值ある地質遺産を有する地域 が，ボトムアップ形式の遺産保全を通じて，その 遺産への意識向上のために地元社会と連動し，お 互いを支援し，その地域の発展に持続可能な方法 を採用している国際協力の仕組みであるとされて いる。

ユネスコの組織に対応して各国の国内組織は国 のユネスコ国内委員会あるいはユネスコ担当の関 連政府機関によって認証されなければならない。 また，国内組織の構成が次のように示されている。 それは，工ネスコ国内委員会あるいはユネスコ 担当の関連政府機関の代表者，国内の地質学組織 あるいは調査所の代表者，国内の環境保護地域の 組織の代表者, 国内の文化遺産団体の代表者, 国 内の観光組織の代表者, IGCP のナショナル・コ ミティの代表者，その加盟国に存在するユネス コ・グローバル・ジオパークの代表者で構成さ れ，国内特有の事情にあわせるのに適当とみられ る場合は異なる追加の構成員を含めることができ る。

国内組織の業務は，ユネスコ・グローバル・ジ オパークへの国の貢献，地質遺産の識別とその重 要性の普及啓発，新規ユネスコ・グローバル・ジ オパークの設立の促進，申請・再認定・拡張の評 価と承認，望む場合は，その加盟国内における審 査あるいは再認定任務への同行，その加盟国の工 ネスコ国内委員会あるいはユネスコ担当の関連政 府機関への，すべてのユネスコ・グローバル・ジ オパーク申請の提出，ユネスコ・グローバル・ジ オパーク相互間の国際協力の推進などである。

日本ジオパーク委員会 (JGC) は日本ユネス コ国内委員会から，2016 年 1 月 25 日付で，ナ ショナルコミッティの認証およびユネスコ世界ジ オパーク事業の登録審査業務機関としての認証を 受けた。その認定証のなかで日本ジオパーク委員 会の役割が明記されており，それらは次のように なっている。 
（1）推薦地域の募集方法についての審議

（2）推薦地域の選考基準の策定

（3）推薦地域の選定

(4) 登録審査に係る調査

（5）その他登録審査に係る必要な事項

現在 JGC は地質，地理，第四紀，地震，火山 の 5 学会で構成されている。日本学術会議には 約 2000 の学会が関連しているが，そのなかでど の学術団体がジオパークに貢献することができる か，あるいは貢献することが望ましいかをつねに 議論していることが必要である。

\section{VIII. ジオパークの教育力}

「教育」という言葉は「教え育てる」という他 動詞であるが，ジオパークの役目はむしろ「学び 習う」という自動詞で表現される「学習」という 言葉で語られる方がいいと思う。ユネスコの概念 でいうボトムアップを基本とするジオパークの活 動を発展させるためには，その地域の市民が自ら 学ぶことによって，はじめて本物の発展になるか らである。

ジオパークにとって重要なことを人の視点から 見ると，もちろんもっとも重要なのはジオサイト を訪れる客である。そして客とジオサイトのイン ターフェイスとして客を迎えるガイドがいる。さ らにそのガイドを支援する専門員などの科学の知 識をもつ人たちがいる。ここではジオパークの教 育力，あるいは学習力を，これらの人たちの実例 を挙げながらそれぞれの立場の教育力あるいは学 習力を考えてみたい。

まず客の例として「おおいた姫島ジオパーク」 と「抄いた豊後大野ジオパーク」を紹介する。 決定したときの記者発表の内容からまずこれらの ジオパークの特徵を述べる。おおいた姫島ジオ パークは，国東半島の沖に浮かぶ多数の単成火山 をもつ島で，西日本各地の考古遺跡で出土する石 器の主原産地である黒曜岩の断崖（国指定天然記 念物）がある。海蝕崖に多様な地層が観察できる ことも特徵である。丘陵をなす地層は激しく褶曲 し，瀬戸内海が陸地であったころの名残であるゾ ウの化石，藍鉄鉱などを包含する。集落はおもに
砂州に立地し，火口跡や潟湖を活用した車えびの 養殖が基幹産業となっている。クルーズ船で海か らの美しい景観を楽しむこともできる。

おおいた豊後大野ジオパークは，約 1 億年前 の地層群を貫くマグマがつくった祖母山の美しい 景観や， 9 万年前の阿蘇火山の巨大噴火があった からこそ生まれた滝や棚田群，井路，石橋群，磨 崖仏など，巨大噴火と人びととの関わりが体感で きる。郷土愛あふれるガイドの解説を聞けば，神 楽や獅子舞などの独自の文化がこの地で培われて きた背景に触れることができる。

姫島全体が姫島村である。温泉で有名な大分県 は地熱の恩恵を受けている地域であるが，火山活 動で生まれた姫島は大分県の象徴といえる。村長 は親子で 50 年以上つとめている方である。姫島 には専門家にとっての研究課題も豊富にある。ジ オサイトの 1 つになっている層内褶曲の仕組み も，まだよくわかっていない。そのようなことを 研究する若い研究者たちに，島に滞在する便宜 と, 研究のための場所と, 少しの資金を提供する ことによって，世界の若い学者の関心を引くこと もありうる。海底の調査もこれからである。アサ ギマダラは，5 月にスナビキソウに立ち寄り，10 月には藤袴に立ち寄る。同じように毎年姫島に立 ち寄る研究者たちが増えるのも島の子どもたちの 学習に役立つことになる。

おおいた豊後大野ジオパークは，大きく 4 つの 地域から成り立っている。北部は，火山噴出物と 中生代の貫入岩類などで構成された大野山地，南 部は，ジュラ紀の付加体で構成される山地，西は 第三紀の火山岩類からなる山岳地帯，そして人び との生活の場となっている大野川盆地である。大 野川盆地には，白覀紀の大野川層群がある，その 上を今から 9 万年前の阿蘇山の 4 回目の巨大噴 火で発生した超巨大火砕流が埋め尽くしている。 この基層となる「阿蘇四火砕流堆積物」が，歴史， 文化，生活に大きく影響している。大分県には磨 崖仏が多く，豊後大野地域にも国史跡「菅尾磨崖 仏」を筆頭に，中世から近世にかけての磨崖仏が ある。阿蘇溶結凝灰岩の大地であることがその要 因になっているのはまちがいない。加工しやすい 
弱溶結凝灰岩露頭, 非溶結の凝灰岩露頭が, 仏像 を彫る場所に選ばれている。

県内で同時に 2 つのジオパークが発足し, 海 に囲まれた姫島の子どもたちと，山に囲まれた豊 後大野の子どもたちが，相互に訪問し体験する機 会が得られた。豊後大野の小学生たちは姫島を訪 問して，明石海岸で海水浴をしたり，丸石鼻では 砂鉄を採取したり，貴重な経験を積んだ。姫島の 子どもたちは，水が流れている大きな川ではじめ て遊び，豊後大野の子どもたちは浮きやすい大き な海ではじめて泳いだ。それらの体験が子どもた ちによっていきいきと語られ，それを支援してき た大人たちは，その報告を懸命に聞いて感動の涙 を浮かべながら拍手を送った。豊後大野の橋本市 長は,「ここには何もない」と言う子どもたちに 出会ってその理由を聞くと，大人たちがそう言う という答えだったという。この意識を，「ここに は素晴らしいものがある」と変えるのがジオパー クだと彼は考えた。姫島の藤本村長も，「何もな い」という住民の意識を「ここにしかない」とい う意識に変えるのがジオパークだという。これら のジオパークでは，子どもの体験を通して，地元 の人たちが自分たちの住む地域の貴重な地球遺産 を認識するという学習をすることができたのであ る。

次にガイドの例である。山陰海岸ジオパークの 公式ホームページを開くと，このジオパークの見 所の画面が次つぎと出てくる。竹野川河口にそび え立つ巨大な一枚岩（京丹後市の立岩）。規則正 しい割れ目が美しい玄武岩（豊岡市玄武洞）。波 食棚が広がる穏やかな入り江（香美町今子浦）。 鮮やかな新緑に覆われたブナ林（新温泉町扇） 山), 白い花崗岩。海と空の色とのコントラスト が美しい岩石海岸 (岩美町城原海岸), 日々表情 を変える海岸砂丘（鳥取市鳥取砂丘）というよう に続く。このジオパークは日本海形成の物語をも つ。地球上から恐竜が絶滅したころの山院海岸 は，まだアジア大陸の東の端に付加体として成長 していた。それが日本海の拡大によって大陸から 分かれて今の場所に移動してきた。約 1600 万年 前には今の日本海ができあがっていて，そのとき
から現在に至る，さまざまの地形や地質が山陰海 岸地域にあり，それらを背景として，動物や植物 があり，人の暮らしや文化，歴史がある。

このジオサイトの例として海岸ではない内陸の 場合を紹介したい。田尻号という但馬牛が，1939 年，現在の兵庫県美方郡香美町小代区貫田の田尻 松蔵宅で生まれた。そして，1958 年まで生きて， 優秀な種牛として和牛の大半を占める黒毛和牛種 の系統をつくった。詳しい調査の結果，全国の黒 毛和種の母牛の $99.9 \%$ が田尻号の子孫であるこ とがわかった。この田尻号の歴史を懸命に調べて 紹介した藤村さんは，小代観光協会の臨時職員 だった。そのことの経緯が，日本ジオパーク・ ネットワークのガイド活動のリーダーの今井ひろ こさんによって紹介された。今井さんによると， 小代のまちあるきガイドチーム「山陰海岸ジオ パーク小代ファンクラブ」と協力してガイド事業 の本格稼働を目指して, 毎月会議やガイドトレー ニングを行ったという。

今井さんは, 2011 年, 香住でジオパーク推進 員としての仕事をはじめたときに藤村美香さんに 出会った。今井さん自身は海で仕事をする立場 で，香美町にスキー場があることも知らなかった という。ジオパーク推進員になって，最初に実行 したことが，町内のジオサイトをすべて見て迴る ことであり，そのなかで小代の見どころを案内し たのが藤村さんだった。山㓌海岸ジオパークは 「海岸」と付いているから，山は関係ないと中山 間地域の人たちが言っていた。それで，山間部の 産業の柱である但馬牛を，今井さんは「山間部で のジオパークの要素の柱にしたいという思いがあ り」，子どものときから牛が大好きで，但馬牛に 詳しい藤村さんに多くのことを聞いたという。ジ オガイド講習会で，藤村さんはそのころ調べてい た但馬牛のことを話した。但馬牛との関連で小代 を宣伝することで，過疎化が進む小代を救うこと になるかもしれないという希望をもっていた。

但馬では今も但馬牛の畜産農家があるが，小代 には，他の地域と決定的に違うものがある。それ は，現在の但馬牛のルーツが小代にあるという歴 史である。明治時代になり，但馬牛が神戸に出荷 
され，食肉として加工されると，食用としての人 気が上がった。そこで大型の牛に改良しょうとし たが成功せず，純血の但馬牛こそが必要だと気づ いたときには混血の但馬牛しかいなかったが，小 代のもっとも奥まった集落にわずか 4 頭だけ，純 血の但馬牛が見つかったのだという。藤村さんは 42 歳で他界したが, 香美町まち歩きガイドは遺 志を継いで，但馬牛と棚田の暮らしを語ってい る。地元の市民の熱意が本物のガイドを生み出す 典型的な実例だと思う。

ガイドが語る方言の魅力も認識しておく必要が ある。ジオパークは大地の恩恵のもとに形成され た歴史と生活の文化を語る場でもある。文化はき わめてローカルなもので, その真髄を語るための 最適の言語はその地域の言葉である。ガイドが本 物の方言で語ることによって文化の実体が，その 現場に来てはじめて理解できることになる。例え ば，室戸岬の隆起地形を語るガイドが，「こじゃ んと大きなマグニチュード 8 以上の地震が 2038 年ごろ起こるがですきに，そのときにはこの岬が また隆起するがですぞね」と語るとき，土地の人 びとのプレート境界地震を繰り返し体験して伝え てきた文化が理解できるのである。

ガイドの心得の基本として，専門用語を使わず に説明するという文章を見かけるが，これは不十 分な表現で，専門用語だけですましてはいけない ということである。単純な思いつきのたとえ話な どで説明するととんでもない誤解を与える場合が ある。間違った知識を伝えてしまう可能性がガイ ドにはつねにつきまとう。これを防ぐためには, ガイド自身がしっかりと学習して自分がまず理解 していることが基本である。そして知らないこと を知らないという強い意志が必要である。

客の質問に対してガイドが知らないと答える場 合には，学習していないので知らない場合，専門 家に聞いても理解できなかったので知らないと答 える場合, 専門の研究者もまだ未知の内容であっ てこれからの研究テーマであるという場合があ る。ジオパークのガイドは，これらの違いを認識 していて明確に区別して伝えることができるガイ ドでなければならない。
ガイドの学習を支援する専門員やアドバイザー の研究者たちは，ガイドが完全に理解するまで丁 寧に学習の相手をすることが重要であり，ガイド の理解の程度を測定する工夫が求められる。それ には実地に客のグループに入って客とのやりとり を聞くことも重要である。研究者にとっては市民 の素朴な質問のなかから重要な研究テーマを見つ けるという愉しみもある。未知のことがあれば, それは科学者の次の研究材料になるからである。 まれではあるが，科学者がガイドの間違いを頭ご なしに批判している場面に出会ったことがある が，それはガイドの学習意欲を減退させることに なる。専門用語の意味を, 基礎知識がなくてもガ イドが理解できるように教える能力が，ジオパー ク活動を支援する科学者たちに求められることで あり，これはジオパークだけでなく現代の社会全 般からの要請でもあるといえる。

ジオパークの地域で未知の研究課題がある場 合，それを研究する若い研究者を世界から公募す ることが，ジオパークの宣伝にもなり，持続可能 なジオパーク活動にもつながる。このことを多く のジオパークに伝えた結果，いくつかのジオパー クで研究費の助成などが行われる例が出てきたこ とはたいへん有意義であろうと思われる。

ジオパークの活動がその地域の市民の自発的な 学習と，それをもとにした他地域との交流やガイ ドの自主的な学習会や交流会によって着実に発展 していくことこそ，ジオパーク活動の目的であ り, ジオパーク活動が持続可能な地域の活動につ ながっていくために必要である。それがジオパー クの教育力ではなく, ジオパークの学習力という べきものではないだろうか。

日本のジオパーク活動が，ユネスコ世界ジオ パークという枠組みのなかでのジオパークと，そ れの国内版としての，日本ジオパークネットワー クへの加盟という独自の制度を発展させてきたこ とによって，日本の文化に即した独自のジオパー ク活動を展開していくことを可能としている。日 本ジオパークネットワークに加盟することが，ユ ネスコ世界ジオパーク加盟への単なる入口や段階 であるという意味ではないという認識が，今後の 
日本のジオパーク活動の基本に存在しなければな らないのではないかと思われる。その上でユネス コ世界ジオパークへ加盟申請の判定基準を策定 し，意義のあるジオパークの将来の姿を，日本ジ オパークネットワークの関係者全員で見いだして いくことが，今後の重要な課題であると思われる。

\section{文献}

Eder, F.W. (2007): Promotion of National Geoparks within the international arena. Proceeding of the Second International Symposium on Development Within Geoparks.

Gray, M. (2004): Geodiversity: Valuing and Conserving Abiotic Nature. John Wiley \& Sons Ltd, Chichester, 434p.

国際環境研究協会編 (2005): 特集 ジオダイバーシ ティ：日本に扔けるその保全と研究の必要性. 地球 環境, 10(2). [Association of International Research
Initiatives for Environmental Studies ed. (2005): Special Issue "Geodiversity: Necessity of Its Conservation and Research in Japan". Chikyu Kankyo, 10 (2). (in Japanese) *]

尾池和夫 ・加藤碵一 ・渡辺真人 (2011): 日本のジオ パーク.ナカニシヤ出版. [Oike, K., Kato, H. and Watanabe, M. (2011): Geoparks in Japan. Nakanishiya Shuppan. (in Japanese) * ]

高木秀雄 (2012): 三陸にジオパークを: 未来のいのち を守るために. 早稲田大学出版部. [Takagi, T. (2012): Geopark to Sanriku: For Life in Future (Sanriku Ni Jiopaku Wo: Mirai No Inochi Wo Mamoru Tameni). Waseda University Press. (in Japanese) *]

Patzak, M. and Missotten, R., 宮野素美子 ・渡辺真人 訳 (2007): ユネスコのジオパーク活動. 地質ニュー ス, 635, 21-24. [Patzak, M. and Missotten, R., Miyano, S. and Watanabe, M. trans. (2007): Geoparks activities of UNESCO. Chishitsu News, 635, 21-24. (in Japanese) *]

${ }^{*}$ Title etc. translated by K.O. 